\title{
MECHANICAL PROPERTIES OF BIO MINERALIZED CONCRETE
}

\author{
Silvia Hanah $\mathrm{S}^{1}$, Sakthieswaran $\mathrm{N}^{2}$ \\ ${ }^{1}$ PG Scholar, Department of Civil Engineering, Regional Office of Anna University, Tirunelveli \\ ${ }^{2}$ Department of Civil Engineering, Regional Office of Anna University, Tirunelveli
}

\begin{abstract}
Quantities of sludge from septic tank and quarry rock dust from industries have been on the rise in recent years due to the rapid improvement in the standard of living and the increase in industrialization. Unfortunately, the majority of sludge from septic tank is not being recycled and hence it causes serious problems on natural resources and environment. For these reasons, this study has been conducted through basic experimental research in order to analyze the possibilities of recycling the sludge from septic tank as a supplementary material in cement concrete. In this research various proportions of septic tank sludge and quarry rock dust are used as supplement to sand in cement concrete and also various proportions of bacterial solutions are used as a supplement to water. The works under taken here dealt with the use of quarry rock dust, septic tank sludge and bacterial water as a supplementary material in cement concrete. In this investigation $\%$ of water absorption and compressive strength criteria were analyzed by introducing septic tank sludge, quarry rock dust and bacterial solution into the cement concrete.
\end{abstract}

Keywords: recycling, septic tank sludge, quarry rock dust

\section{INTRODUCTION}

Concrete is the most commonly used building material but the cracks in concrete create problem. Cracks in concrete occur due to various mechanisms such as shrinkage, freezethaw reactions and mechanical compressive and tensile forces. Cracking of the concrete surface may enhance the deterioration of embedded steel bars. Therefore a novel technique has been developed by using a selective microbial plugging process in which microbial metabolic activities promote calcium carbonate (calcite) precipitation. This technique is referred as (Bio mineralization) microbiologically enhanced crack remediation (MECR). In this technique ureolytic bacteria is used. Hence the concrete is called bacterial concrete. The bacterial concrete can be prepared by adding spore forming bacteria in the concrete that are able to continuously precipitate calcite, this process of production of calcite precipitation is called microbiologically induced calcite precipitation (MICP) . In this research an environment friendly and autonomous crack repair technique is explored.

\section{BIOMINERALIZATION PROCESS}

Bio mineralization is defined as a biologically induced precipitation in which an organism creates a local micro environment conditions that allow optimal extracellular chemical precipitation of mineral phases. Almost all bacteria are capable of calcium carbonate precipitation. Bio mineralization of calcium carbonate is one of the strategies of remediate cracks in building materials.

Calcium ions in the solution are attracted to the bacterial cell wall due to the negative charge of the later. Upon addition of urea to the bacteria, dissolved inorganic carbon and ammonium are released in the micro environment of the bacteria. In the presence of calcium ions, this can result in a local super saturation and hence heterogeneous precipitation of calcium carbonate on the bacterial cell wall.

$$
\mathrm{Ca}^{+2}+\mathrm{CO}_{3}{ }^{2-} \rightarrow \mathrm{CaCO}_{3}
$$

\section{MATERIALS AND THEIR PROPERTIES}

The following materials are used in this study

1. Sand

2. Cement

3. Quarry Rock dust

4. Sludge from Septic Tank

5. Bacteria

\subsection{Sand}

Medium size sand from a local quarry near Nagercoil with a modulus of fineness $=2.80$, Specific gravity 2.677 , normal grading with the silt content $0.8 \%$

\subsection{Cement}

Ordinary Portland Pozzolana Cement (Fly ash based) conforming to BIS(Part1):1991having specific gravity of 3.15 was used. The consistency value becomes $30 \%$ and the initial and final setting time were 90 and 195 minutes respectively.

\subsection{Quarry Rock Dust}

The quarry rock dust was obtained from local crusher at Kumarapuram , Tirunelveli District. The specific gravity of the quarry rock dust is 2.677. Moisture content and bulk density of waste are less than the sand properties. 


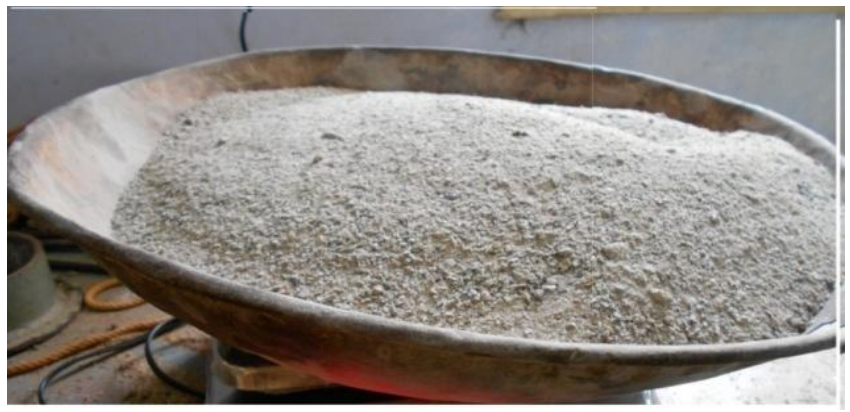

Fig 3.1 Quarry rock dust

\subsection{Sludge from Septic Tank}

Settled material from either bacterial activity or yeast activity is called as sludge. Inorganic or inert solid materials and the by products of bacterial digestion, sink to the bottom of tank and form a layer commonly known as sludge. It is not biodegradable and will not decompose.

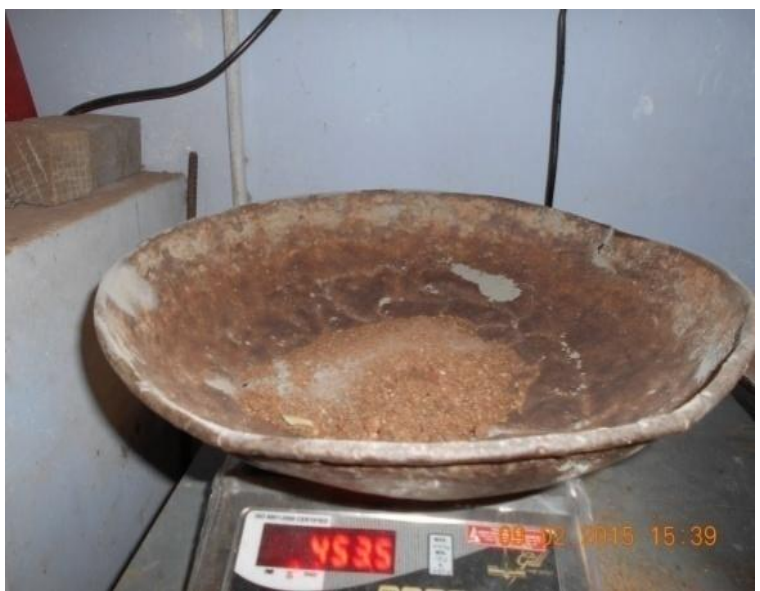

Fig 3.2 Sludge

\subsection{Bacteria}

Bacteria is able to influence the precipitation of calcium carbonate by the production of urease enzyme. This enzyme catalyzes the hydrolysis of urea to $\mathrm{CO}_{2}$ and ammonia, resulting an increase of $\mathrm{P}^{\mathrm{H}}$ and carbonate concentration in the bacterial environment. Bacteria (Singular-Bacterium) are relatively simple, single celled (Unicellular) organisms. Bacteria have a wide range of shapes ranging from spheres to rods and spirals. There are typically 40 million bacterial cells in a gram of soil and a million bacterial cells in a millilitre of fresh water

\subsubsection{Culture of Bacteria}

$15 \mathrm{gm}$ yeast and $4 \mathrm{gm}$ sugar is mixed with $450 \mathrm{ml}$ of water and the bacteria is cultivated in lactose broth solution for one hour.

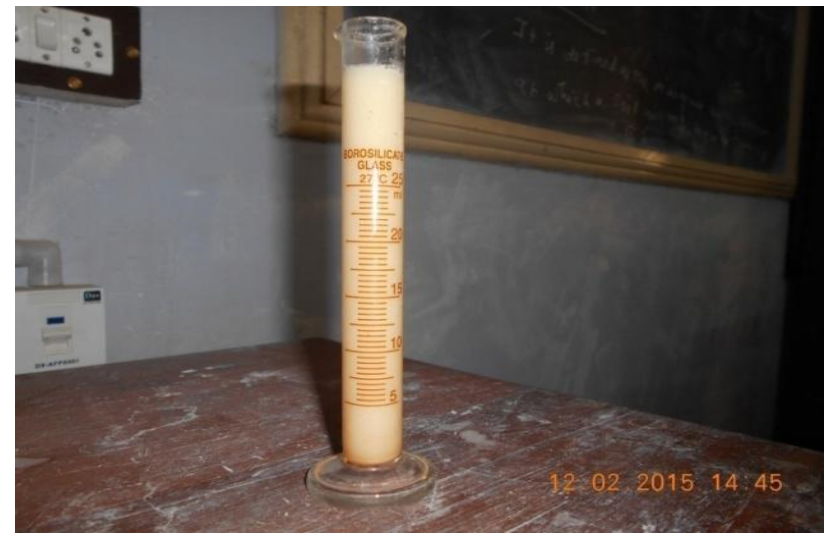

Fig 3.3 Culture of bacteria

\section{METHODOLOGY}

Replacement of sand by various supplementary materials like septic tank sludge and quarry rock dust and also replacement of water by bacterial solution as supplementary material are used in this study with different proportions based on the literature review. In all mixes, cement is kept as constant. In mix A, cement and water are taken as constant then by varying sludge as $5,10,15 \%$. In mix-B cement and water are taken as constant then by varying quarry rock dust as $10,20,30 \%$.In mix $-\mathrm{C}$ cement and sand are taken as constant then by varying bacterial solution as $5,10,15 \%$. The basic mix proportions used for the trial mixtures are as pe IS: 10262-2009 mix design procedure. The material for each mix proportion is mixed separately. $\mathbf{M}_{20}$ grade concrete is used for this research.

\subsection{Tests On Concrete}

$>$ Compressive strength test

$>$ Water absorption test

\subsubsection{Compressive Strength Test}

Compressive test is the most common test conducted on hardened concrete, partly because it is an easy test to perform, the partly because most of the desirable characteristic properties of concrete are qualitatively related to its compressive strength. The cube specimen is of the size $150 \times 150 \times 150 \mathrm{~mm}$. The fresh concrete were cast and allowed to set for 24hours before being removed from the moulds and kept at room temperature $\left(20^{\circ} \mathrm{C}\right)$. Compressive strength for each mortar mixture was obtained from an average of 3 specimens.. The tests are done on Compressiontesting machine and compressive load is applied on opposite faces axially, slowly at the rate of $140 \mathrm{Mpa} / \mathrm{minute}$. The compressive load is noted for the ultimate failure. Record the total maximum load indicated by the testing machine, and calculates the compressive strength as follows: $\mathrm{F}_{\mathrm{ck}}=\mathrm{P} / \mathrm{A}$

\subsubsection{Water Absorption Test}

Three cubes of size $150 \mathrm{~mm}$ were casted for each mix. All specimens were removed after 24 hours of casting and subsequently water cured for 24 hours. Samples were removed from water and wiped out any traces of water with damp cloth and difference in weight was measured. 


\section{RESULTS AND DISCUSSIONS}

\subsection{Water Absorption Test}

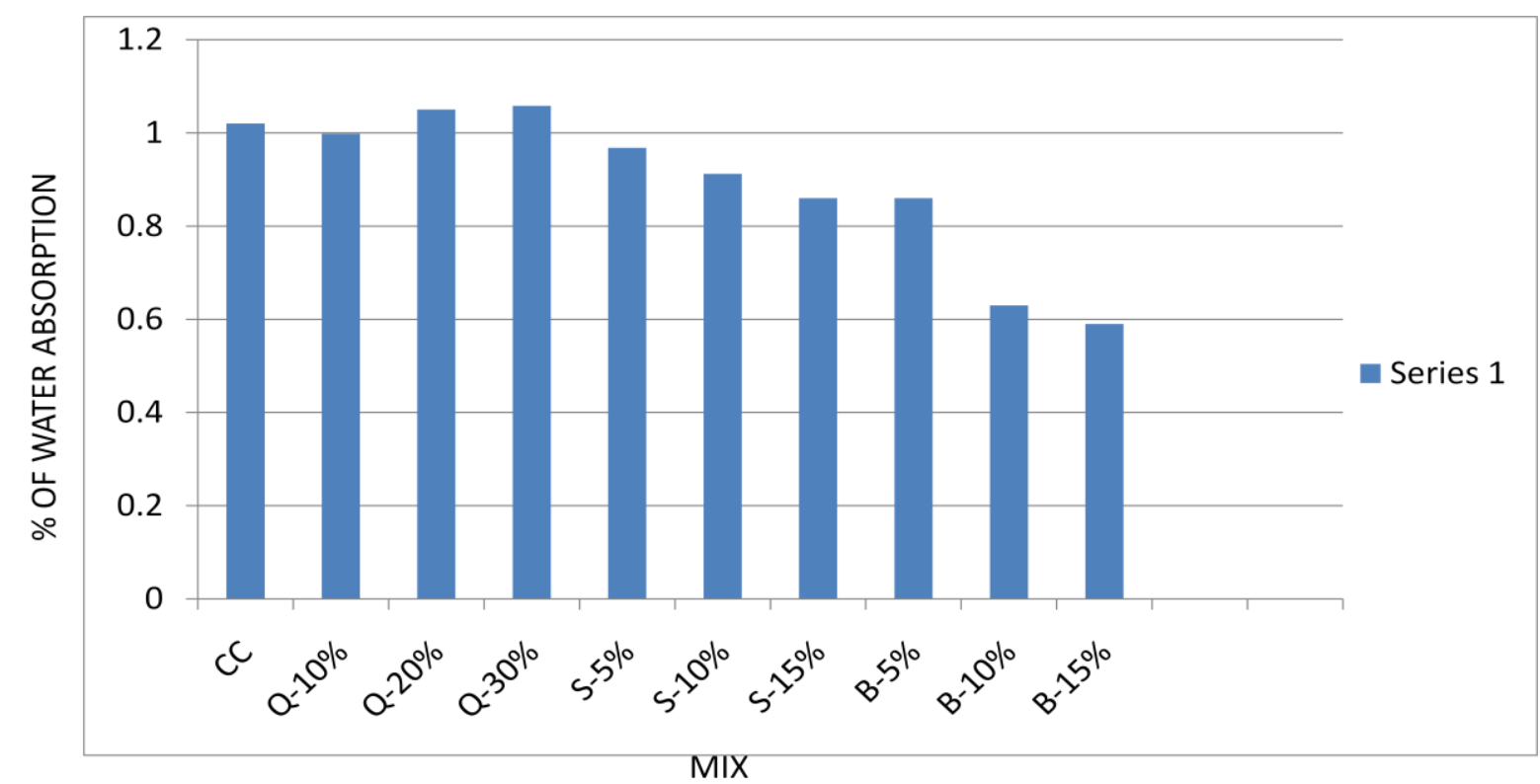

Fig 5.1 Water absorption test

Fig 5.1 shows the percentage of water absorption for various types of mixtures at the age of twenty four hours curing. The absorption characteristics indirectly represent the porosity. The result clearly shows that the mix containing quarry rock dust can have more percentage of water absorption (ie. \% of voids) when compare to control concrete. But the inclusion of sludge and bacterial solution can improve considerably the resistance of water penetration of concrete(ie.reduce the percentage of voids) Bacteria precipitates the calcite crystals which is of cubical in shape plug the pores as well as cracks inside the concrete. The percentage water absorption in mixture containing sludge decreased by $10.5 \%$ compared to control concrete. And also the percentage of water absorption in mixture containing bacterial solution decreased by $32 \%$ compared to control concrete. The incorporation of bacteria into the concrete precipitates the calcite crystals which is of cubical in shape plug the pores as well as cracks inside the concrete. All the bacterial containing mixtures show better result when compared to control and other mixtures. Water absorption for various mixes is in the order of B-15\% <B$10 \%<\mathrm{B}-5 \%<\mathrm{S}-15 \%<\mathrm{S}-10 \%<\mathrm{S}-5 \%<\mathrm{Q}-30 \%$. Bacteria precipitates the calcite crystals which are of cubical in shape plug the pores as well as cracks inside the concrete.

\subsection{Days Compressive Strength}



MIX

Fig 5.2 28 Days Compressive Strength 


\subsection{Compressive Strength for Various Types of Mixes}

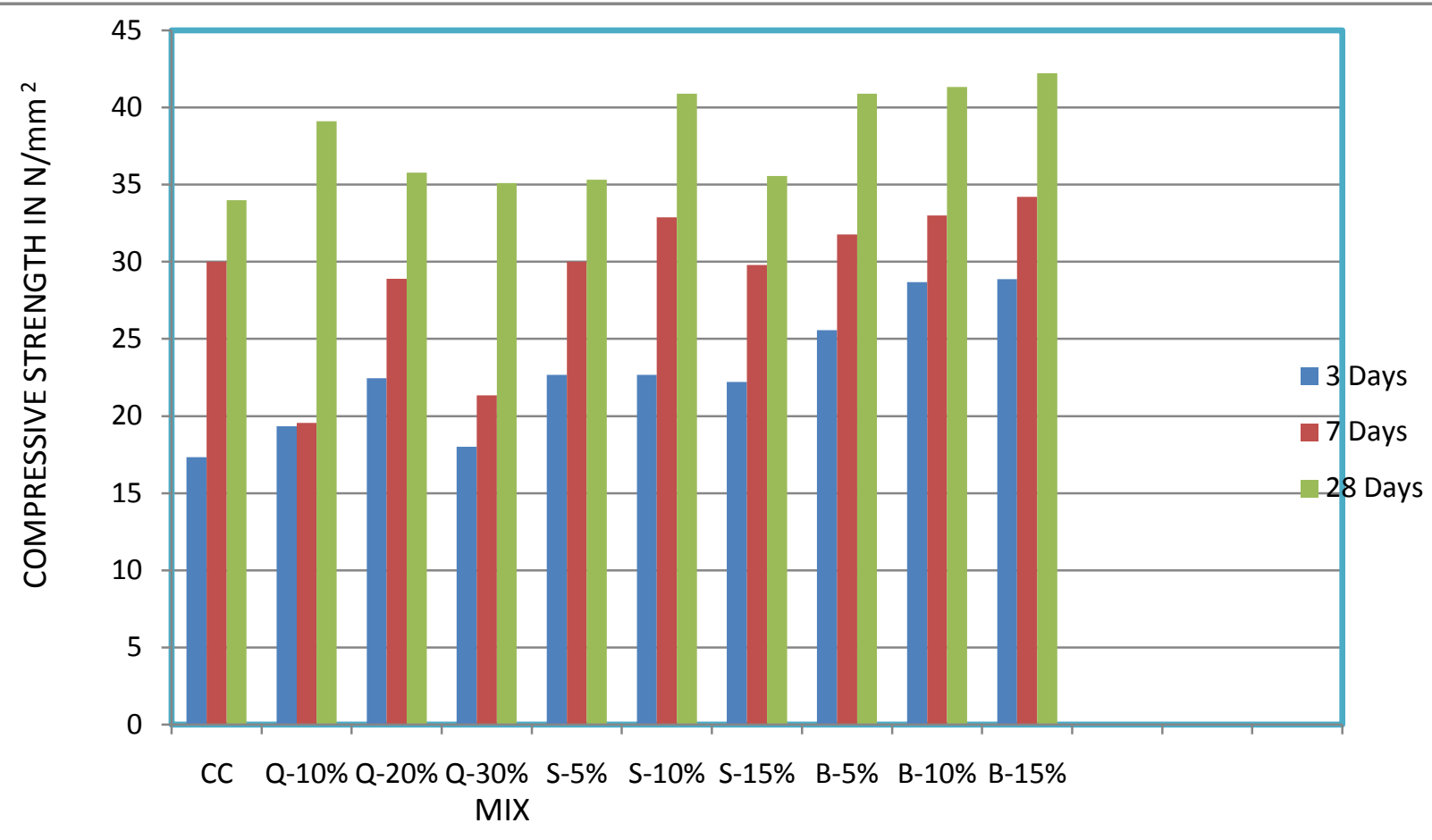

Fig.5.3 Compressive strength for various types of mixes

Table 5.1 Details of mix proportion

\begin{tabular}{|l|l|l|l|l|l|l|l|}
\hline & Mix Id & $\begin{array}{l}\text { Cement } \\
\mathbf{\%}\end{array}$ & $\begin{array}{l}\text { Sand } \\
\mathbf{\%}\end{array}$ & $\begin{array}{l}\text { Sludg } \\
\mathbf{e} \\
\mathbf{\%}\end{array}$ & $\begin{array}{l}\text { Quarry } \\
\text { rock dust } \\
\mathbf{\%}\end{array}$ & $\begin{array}{l}\text { Bacterial } \\
\text { Density by Wt. } \\
\text { Of Water \% }\end{array}$ & Water \\
\hline & & & & & & & \\
\hline Control mix & CC & 100 & 100 & - & - & - & 100 \\
\hline Mix A(Trial1) & S -5 \% & 100 & 95 & 5 & & - & 100 \\
\hline MIXA(Trial 2) & S-10 \% & 100 & 90 & 10 & & - & 100 \\
\hline MIX A(Trial 3) & S -15\% & 100 & 85 & 15 & & & 100 \\
\hline MIX(B)(Trial 1) & Q-10\% & 100 & 90 & - & 10 & & 100 \\
\hline MIX(B) (Trial2) & Q-20\% & 100 & 80 & & 20 & & 100 \\
\hline MIX(B) (Trial3) & Q-30\% & 100 & 70 & & 30 & & 100 \\
\hline MIX-C(Trial-1) & B-5\% & 100 & 100 & & & 5 & 95 \\
\hline MIX-C(Trial-2) & B-10\% & 100 & 100 & & & 10 & 90 \\
\hline MIX-C(Trial-3) & B-15\% & 100 & 100 & & & 15 & 85 \\
\hline
\end{tabular}

Table 5.2 water absorption test

\begin{tabular}{|l|l|l|}
\hline S:NO & MIX & \% OF WATER ABSORPTION \\
\hline 1 & CC & 1.02 \\
\hline 2 & Q-10\% & 0.9975 \\
\hline 3 & Q-20\% & 1.05 \\
\hline 4 & Q-30\% & 1.058 \\
\hline 5 & S-5\% & 0.968 \\
\hline 6 & S-10\% & 0.912 \\
\hline 7 & S-15\% & 0.86 \\
\hline 8 & B-5\% & 0.86 \\
\hline 9 & B-10\% & 0.63 \\
\hline 10 & B-15\% & 0.59 \\
\hline
\end{tabular}


Table 5.3 Compressive strength for various types of mixes

\begin{tabular}{|l|l|l|l|}
\hline MIX & COMPRESSIVE STRENGH IN N/mm ${ }^{2}$ & 28 DAYS \\
\hline & 3 DAYS & 7 DAYS & 34.00 \\
\hline CC & 17.33 & 30.00 & 39.11 \\
\hline Q-10\% & 19.33 & 19.55 & 35.78 \\
\hline Q-20\% & 22.44 & 28.89 & 35.11 \\
\hline Q-30\% & 18.00 & 21.33 & 35.33 \\
\hline S-5\% & 22.67 & 30.00 & 40.89 \\
\hline S-10\% & 22.67 & 32.89 & 35.55 \\
\hline S-15\% & 22.22 & 29.78 & 40.89 \\
\hline B-5\% & 25.56 & 31.78 & 41.33 \\
\hline B-10\% & 28.67 & 33.00 & 42.22 \\
\hline B-15\% & 28.88 & 34.22 & \\
\hline
\end{tabular}

Fig 5.3 shows the 3days,7days and 28days compressive strength of various types of mixes. The compressive strength of cement concrete made with PPC (i.e. the control) is compared to concrete made with quarry rock dust, sludge and bacterial solution. $15 \%$ bacterial density revealed the highest compressive strength, where it recorded a $24 \%$ increase in compressive strength with respect to the control specimen and it also reaches the strength of control concrete at the age of 7 days itself. The compressive strength of specimens containing quarry rock dust, sludge and bacterial solution is higher than the control concrete. Mix S - 10\% which contained $10 \%$ of sludge achieved a $20 \%$ increase in compressive strength with respect to the control concrete. This indicates that the sludge and bacteria greatly improves the mechanical performance of concrete.

\section{Further Studies}

Future studies need to focus by increasing the percentage of bacteria content above $15 \%$ of partial replacement of water.

\section{CONCLUSION}

The various combinations of cement, sand, coarse aggregate, quarry rock dust, sludge and bacterial solution were mixed and casted into $150 \mathrm{~mm}$ cubes and tested for their water absorption and compressive strength at 3 days, 7 days and 28 days curing.

- All the experimental data shows that addition of sludge, quarry rock dust and bacterial solution improves the strength. From the above study, it is concluded that the sludge and quarry rock dust may be used as a replacement material for fine aggregate.

- The replacement of water by bacterial solution gives an excellent result in strength and quality aspect. The results showed that $15 \%$ replacement of water by bacterial solution induced $24 \%$ increase in compressive strength when compared to conventional concrete and percentage of water absorption is decreased by $32 \%$ compared to control concrete.

- the water absorption test result clearly demonstrate that percentage of water absorption in mixture containing sludge decreased by $10.5 \%$ compared to control concrete and the water absorption of mixture containing quarry rock dust is slightly higher than conventional concrete.

- $\quad$ The use of quarry rock dust, sludge and bacteria exhibited excellent performance due to the efficient micro filling ability. Therefore, the results of this study provide a strong recommendation for the use of quarry rock dust and sludge as fine aggregate in concrete manufacturing.

- From the above investigation,it can be concluded that bacteria can be easily cultured and safely used in improving the performance characteristics of concrete.

\section{REFERENCES}

[1] Yagüe A, Valls S, Vázquez E and Kuchinow.V. "Study of hydration of cement pastes and dry sewage sludge". Proceedings of the International Chen, Zhimin He, Guoliang Zhang Study on Performance of Concrete Made from Sewage Sludge Ceramsite

[2] Du X. Research on technology and batch formula of sintering municipal sewage sludge for manufacturing haydite. Sichuan Building Mater 2009; 4: 61-63.

[3] M. Jamshidia, A. Jamshidib and N. Mehrdadib Application of Sewage Dry Sludgeas Fine Aggregatein Concrete.

[4] Symposium by the Recycling and Reuse of Sewage Sludge at the University of Dundee, Scotland, UK on 19-20 March 2001, 253-261.

[5] Jamshidi, M. Jamshidi, ,N. Mehrdadi, A. ShasavandiMechanical Performance Of Concrete With Partial Replacement Of Sand By Sewage Sludge Ash

[6] S. Valls, A. Yague, E. Vazquez, C. Mariscal, Physical and mechanical properties of concrete with dry sludge from sewage treatment plant, Cement Concrete Research, 34 (2004) 